\title{
Community-Based Factoring Companies and Small Business Lending
}

by

Dimitri B. Papadimitriou*

Ronnic J. Phillips**

L. Randall Wray***

Working Paper No. 108

April 1994

The authors would like to thank Steve Fazzari, John Caskey, and Walker Todd for comments and Rick Eichhom for research assistance.

*The Jerome Levy Economics Institute of Bard College

**Colorado State University, Fort Collins, Colorado and The Jerome Levy Economics Institute of Bard College

***University of Denver, Denver, Colorado and The Jerome Levy Economics Institute of Bard College 


\section{INTRODUCTION}

Bank profits have rebounded in the past two years, and bank net worth is now well in excess of regulatory minimums. However, there is widespread concern that the improvement of financial conditions in the commercial banking sector has not induced additional lending--particularly lending to small business. Although until recently the depressed state of demand in the US has lowered the demand by small business for loans, trends in commercial banking make it unlikely that commercial banks will be willing and able to meet small business demand for loans even now that the economy is recovering.

There is widespread recognition that our financial institutions are not providing an adequate level of services to certain identifiable segments of our communities, including low income and minority households and businesses--especially in depressed neighborhoods. Recent detailed studies have demonstrated that such neighborhoods are systematically denied equal access to home mortgage loans (Munnell et al, 1992; Bradbury, Case, and Dunham 1989; Carr and Megbolugbe 1993). While similar data for commercial lending is not available, anecdotal evidence suggests that firms in these neighborhoods are also underserved. Jerry Jordan, President of the Federal Reserve Bank of Cleveland, recently noted:

Improving access to credit by minority and low-income communities represents a serious challenge to lenders, community residents, and government officials. ... The deplorable condition of a lot of our neighborhoods in major cities across this country is clear evidence that something is terribly wrong ... The solution to this problem is economic development, an indispensable component of which is an effective banking system (Jordan 1993).

Governor Lawrence Lindsey of the Federal Reserve Board echoed Jordan by saying: "no single consumer issue is of greater concern than ensuring that the credit-granting process in the institutions that we regulate is free of unfair bias" (Lindsey 1993, 10). 
In two recent Public Policy Briefs published by the Jerome Levy Economics Institute, we proposed the creation of a system of Community Development Banks (CDBs) to increase the provision of financial services to economically distressed communities. As part of our proposal, we advocated that the CDBs provide a range of services to small businesses in these communities to provide employment opportunities and to revitalize communities. We also called for strengthening of the Community Reinvestment Act (CRA), with CDB lending in distressed communities counting toward commercial bank fulfillment of CRA requirements when more traditional financial institutions invest in such community-based lenders.

Lending to small business can be strengthened even further by encouraging the development of "niche" financial institutions that would supplement the activity provided by CDBs and commercial banks. This Public Policy Brief focuses on the role that can be played by communitybased factor companies. Factors supply credit to firms as they purchase accounts receivable; in addition, they provide a wide range of other financial services. It is our belief that factors can play an important role in increasing the supply of credit and other financial services to small businesses, if they are made a part of a coherent strategy of community reinvestment. In particular, if the CRA is strengthened and if investment by commercial banks in communitybased factors is counted toward CRA compliance, then the already significant role (at the small firm and community level) played by community-based factors in providing financial services to small business will be enhanced. In addition, the development of a nation-wide system of CDBs should include a role for community-based factors. In some cases, community-based factors could be members of the CDB system; in other cases, some CDBs might include factoring as one of the services that is provided to the community.

The legislation offered by the Administration to provide funding and technical assistance to Community Development Financial Institutions (CDFIs) has been approved by both the House and the Senate. This proposal will provide $\$ 382$ million over four years to CDBs, community development credit unions, community development loan funds, micro-enterprise funds, and community development corporations. In addition, President Clinton called for reform of CRA. 
After a series of public hearings, the agencies in charge of regulating and supervising banks have proposed new CRA regulations. Most importantly, the proposed changes would establish quantifiable service tests, would require more disclosure of lending to small businesses, small farms and consumers, and would encourage investments in CDFIs. We will argue that in some cases, community-based factors should be eligible for funding and assistance under the President's plan, and that investment by banks in these factors should count toward fulfillment of the new CRA regulations.

\section{BANK CONCENTRATION AND SMALL BUSINESS LENDING}

Recent evidence reported by the Federal Reserve Bank of Dallas indicates that small business loans make up 15\% of total loans at insured commercial banks; indeed, these loans make up $44 \%$ of all business loans (Klemme 1993). However, the distribution of small business loans across commercial banks is very skewed: small banks are the most active lenders to small business. The average asset size of active lenders to small business is only $\$ 100$ million; in contrast, the average asset size of the least active lenders to small business is $\$ 1.2$ billion. Furthermore, small banks tend to make smaller loans: the typical bank with less than $\$ 100$ million in assets makes loans of less than $\$ 100,000$, while the typical bank with assets in excess of $\$ 1$ billion focuses on loans of at least $\$ 1$ million.

However, small banks in the US account for a small proportion of total lending. In 1987, less than 200 banks, representing the top $0.9 \%$ of U.S. commercial banks, held $59.3 \%$ of all bank assets (Boyd and Graham 1992). The top ten banks in 1990 held $22 \%$ of all banking assets and the top 25 held 38\%. If a "small" bank is defined as one with $\$ 50$ million in assets in 1984 and $\$ 66.3$ million in 1992 (to account for inflation), then there were 9217 small banks in 1984, accounting for $64 \%$ of all banks but only $8.6 \%$ of all bank assets; by 1992 , there were only 6,692 small banks (59\% of the total), holding only $6.3 \%$ of total assets (Wheelock 1993). 
Between 1986 and 1993, nearly 4250 banks were closed; of these, 1021 were closed due to insolvency, 2043 were converted to branches of bank holding companies, and 1175 were purchased by other banks (DeYoung and Whalen 1994). During the same period, almost 1100 new bank charters were issued--which compensated for those lost to insolvency. The net change in number of banks over the period, however, represented a large loss of the number of banks due to mergers. Even more importantly, however, is the loss of independent (and primarily small) banks: more than 6500 independent banks were lost between 1988-93, many of these were acquired by bank holding companies. The asset share of independent banks fell from $22 \%$ in 1980 to $6 \%$ by 1993 (Nolle 1994). This is significant because small, local, independent banks can be an important source of credit to local business.

Table I gives a size distribution of insured commercial banks in 1988 and 1993. The dramatic downward trend in banks in the smallest size category (less than $\$ 25$ million) is evident from the nearly $50 \%$ drop in their number since 1988 . At the same time, the number of banks in the largest size category, over $\$ 5$ billion, has grown by nearly $25 \%$.

Table I: Number of banks by size, 1988 and 1993

Asset Size Total Number of banks Total Number of banks

(September 1993) (December 1988)

Less than $\$ 25$ million $\quad 2,314 \quad 4,040$

$\$ 25-\$ 100$ million $\quad 5,544 \quad 6,135$

$\$ 100-\$ 300$ million $\quad 2,122 \quad 1,889$

$\$ 300$ million-\$1 billion $\quad 631 \quad 557$

$\$ 1-\$ 5$ billion $\quad 251 \quad 262$

Over $\$ 5$ billion $\quad 115 \quad 99$

Total Number of Banks: $\quad 10,977 \quad 12,982$

Source: Uniform Bank Performance Report, Federal Financial Institutions Examination Council. 
To some extent, the data on numbers of small banks can be misleading for two reasons. First, loss of small banks is offset to some extent by rising numbers of bank branches; the total number of bank offices (banks plus branches) grew by over 20\% during the period from 1980-1991 (Nolle 1994). Second, many of the losses are attributed to mergers so that loss of the bank does not necessarily mean loss of the bank office. However, it is our belief that acquisition of small, independent banks by larger bank holding companies can over a period of time lead to a change of operating procedure that could make it more difficult for small, local business to obtain loans (or, at least, to obtain loans on unchanging terms). Indeed, acquisition often occurs on the justification that the acquiring bank will "rationalize" operations and cut costs; it is often claimed that a small loan costs as much to administer as a large loan. Attempts to cut operating costs can lead to a credit crunch for small firms.

The impact on lending by small banks can be seen in Table II. Not surprisingly, the total volume of loans by banks with less than $\$ 25$ million in assets fell 37\% between 1988 and 1993 . At the same time, the volume of loans by banks with over $\$ 5$ billion in assets grew by $18 \%$. Admittedly, this does not prove definitively that the number of small loans has declined (we have not been able to obtain data on the size of loans made across bank categories), however, because small banks tend to make small loans, while big banks make big loans, the data presented supports the presumption that small business loans have decreased in number. To be sure, when a small bank merges into a larger one, the established small firm-small bank relationships are not necessarily destroyed post-merger, but the terms will most likely change including costlier minimum balance requirements and increased fees. Thus, as mentioned above, the reduction of lending by small banks could contribute to a credit crunch for small firms. 
Table II: Total Bank Loans by size of bank (percent of total loans) and Change in bank loans, 1988 and 1993 (in billions).

$\begin{array}{llll}\text { Asset Size } & \begin{array}{l}\text { Total Loans } \\ (\text { September 1993) }\end{array} & \begin{array}{l}\text { Total Loans } \\ \text { (December 1988) }\end{array} & \% \text { Change } \\ \text { Less than } \$ 25 \text { million } & \$ 18.96(1 \%) & \$ 30.20(2 \%) & -37 \% \\ \$ 25-\$ 100 \text { million } & \$ 158.19(8 \%) & \$ 170.66(9 \%) & -7 \% \\ \$ 100-\$ 300 \text { million } & \$ 192.08(9 \%) & \$ 178.69(9 \%) & +7 \% \\ \$ 300-\$ 1 \text { billion } & \$ 193.16(9 \%) & \$ 178.09(9 \%) & +7 \% \\ \$ 1-\$ 5 \text { billion } & \$ 338.47(16 \%) & \$ 371.27(19 \%) & +9 \% \\ \text { Over } \$ 5 \text { billion } & \$ 1,177(57 \%) & \$ 996(52 \%) & +18 \% \\ \text { Total Loans: } & \$ 2,077.86 & \$ 1,924.91 & +8 \%\end{array}$

Source: Uniform Bank Performance Report, Federal Financial Institutions Examination Council.

Thus, the rising concentration in the commercial banking sector would suggest that small businesses are finding it increasingly difficult to maintain a relation with a small bank that would be interested in making loans that suit their needs. Anecdotal evidence suggests that this is the case, as indicated by numerous stories in the popular and financial press about a "credit crunch" facing small business.

Admittedly, hard data on this credit crunch are hard to obtain. There are no convenient data which categorize business firms according to access to capital markets, although the Federal Reserve Board flow of funds data provide some evidence on small firm finance. While the limited data available indicate that bank lending to small business has increased since the $1980 \mathrm{~s}$, this increase is largely due to a rise of commercial mortgage lending by banks (French 1994, 20). The financial press, however, provides substantial anecdotal evidence. "For many small businesses, obtaining traditional credit based on their balance sheets or anticipated cash flow has 
been more difficult. Factoring has become a convenient method to satisfy their working capital requirements" (Slater 1993, p. 38). It is easy to find similar statcments in the financial press.

Somewhat surprisingly, there appears to be no evidence that specialization in small business loans is less profitable--other considerations are driving the trend to consolidation in commercial banking, which increases bank size beyond the scale that makes small loans attractive. Small firms rely to a much greater extent on commercial banks than do large firms, which have at their disposal many alternative forms of financing that are generally not available to small firms-including commercial paper. In October 1993, total commercial paper outstanding was $\$ 550$ billion, while total commercial and industrial lending of all commercial banks was $\$ 586$ billion (Federal Reserve Bulletin, February 1994). The commercial bank share of U.S. financial assets held by all financial service firms was $51.2 \%$ in 1950 , but only $26.6 \%$ in the third quarter of 1992. Similarly, Simonson (1994) reports that the ratio of finance company business credit to bank commercial and industrial loans rose from $20 \%$ in 1982 to 55\% in 1992. This declining share of the financial services market held by commercial banks affects smaller business to a greater extent because it has fewer non-commercial bank options.

There are other causes of the reduction of the supply of credit to small business in the near term. Small firms rely to a greater extent on collateral and "asset-based" lending than do large firms; in particular, small firm borrowing is frequently based on real estate values. The short term financing of inventories is also an important collateralized loan for small firms, especially single family proprietorships. Deregulation, fear of litigation (product safety, environmental problems), fear of interest rate fluctuations, and unstable exchange rates have all eroded banker faith in longestablished rules of thumb regarding debt-to-equity ratios and cash flow-to-debt coverage ratios (Schlegel 1990). This, in turn, has caused banks to raise the standards and costs of asset-based lending in which collateral must be pledged. Further, problems experienced during the 1980s have caused banks to be cautious and conservative when lending against assets, enhancing the "credit crunch" faced by firms. Of even greater concern is that asset-based lending works against small but growing firms that have large orders to be filled, but lack the financial means to 
expand production. These firms typically find that potential revenues are growing faster than actual productive capacity. A tightening of conditions on collateral based lending exacerbates this situation and these firms become growth-constrained (Schlegel 1990) .

There is considerable anecdotal evidence that small firms are facing a "credit-crunch" that hinders economic recovery. The conventional wisdom is that small business will be the driving force that leads a nation down the path of economic growth, because nearly half of the nation's output is produced by small firms (Samolyk and Humes 1993) and because many economists believe that employment growth will occur first among small firms (Birch and Medoff 1993). There is some controversy over whether small business is normally the driving force, however (Davis, Haltiwanger and Schuh 1993). While we do not want to rely solely on small business to lead the economy out of stagnation, we do recognize that it can play an important role nationally, and in many cases a decisive role regionally and locally. If, as the anecdotal evidence appears to indicate, lack of finance is preventing small firms from undertaking potentially profitable projects, then efforts must be made to increase the supply of credit to small business. Again, however, we do not want to overemphasize the importance of small business lending; depressed neighborhoods will require a variety of programs to restore vitality--including programs that will increase mortgage and home rehabilitation lending, programs to provide more training and more jobs, programs that increase the supply of payment and savings facilities, and programs designed to promote entrepreneurship.

\section{THE ROLE OF FACTORING COMPANIES IN ALLEVIATING THE CREDIT CRUNCH}

As will be discussed, a factor raises funds by issuing commercial paper, notes, and debentures; it purchases accounts receivable from clients, advancing about $80 \%$ of the value of the receivables; and it takes over billing and collection of the accounts. Once customers have paid their bills, the factor pays the remaining value of the invoices to its client, after deducting a discount fee that ranges from $1 \%$ to $5 \%$, plus interest charges on the advance that was made. In 
addition, factors can offer a wide range of financial services to clients, as will be discussed below.

Factor companies have traditionally served small-to-medium sized firms engaged, primarily, in textiles and apparel. Until the 1960s, factors were usually independent and closely linked to the clients they serviced. However, in recent decades there has been a trend toward consolidation that has led to a two-tier factor sector comprised of a few dominant, typically bank-owned, large factors and a declining number of small, independent factors. At the same time, factors have moved into new areas (such as health care, footwear, furniture, housewares, electronics, and foreign trade) and into new financing arrangements. In general, the smaller, independent factors have been more creative in developing new products, however, their client base has been eroded by consolidation in their traditional textile and apparel sectors. This is particularly true for those small factors that specialized in providing finance for small retail stores. In the aggregate, the majority, in terms of numbers of customers of clients of factors, are retailers. As retailers consolidate, independent factors find their business shrinking. Thus, even while the volume of factor business grows quickly, the number of factors and the number of customers serviced by factors is likely to decline (Stuchin 1991). This is countered to some extent by the expansion of factoring beyond its traditional apparel industry base.

However, smaller independent factors are finding that they can compete in "niche" markets as they service primarily smaller, growth-oriented firms whose business is outside the traditional factor business--textiles and apparel--by providing specialized services that these firms cannot obtain from commercial banks and other competitors (Remolona and Wulfekuhler 1992; Doherty 1993). These factors are willing to take equity interests in their clients, and they will make secured and unsecured loans in excess of collateral offered. They are able to offer management advice, take over costly bookkeeping, credit, and collection services that small businesses are frequently happy to unload so they may focus on what they do best. In short, factors are able to fill a gap and to alleviate the credit crunch at least in some cases. 
Factoring has advantages and disadvantages when compared to commercial banking. Factors are not subject to the supervision and regulation imposed on commercial banks unless they are part of a bank holding company. For example, factors are able to avoid writing-off loans and absorbing losses that banks would be required to recognize. While this is potentially a source of risk--and, in the bankruptcy of United Factors, a large factoring concern, unrecognized losses played a major role (Rutberg 1989)--it also makes it possible for a factor to work closely with its client to work out of problems. Given the "people-intensive" nature of small scale factoring, the credit department of a factor is well-positioned to monitor the financial condition and to judge whether work-outs will be cheaper than calling-in loans and forcing bankruptcies. Factors enhance the balance sheets of their clients in a way that cannot be duplicated by commercial banks. When a client sells its accounts receivable to a factor, its debt-to-equity and debt-to-asset ratios are improved, increasing its credit-worthiness. Thus, use of a factor can make it easier for the small business to obtain bank finance. Furthermore, the factor's balance sheet is more favorably impacted by the purchase of accounts receivable than a bank's balance sheet when it accepts accounts receivable as collateral against a loan. (We will return to these points later.)

Factors are also in a unique position to engage in "pipeline finance" as they finance two or more borrowers as a product is moved through the entire production and marketing process, beginning with raw materials and ending with retail sales. Finally, factors apparently did not engage in "fad lending" to which commercial banks succumbed during the 1980s--in LDC lending, commercial real estate, energy loans, and residential housing (Andersen Consulting 1990b). Even where bankowned, factors did not experiment with the types of loans that proved later to have high default rates. The only important exception was in the area of LBOs, where factors played a role in providing some of the finance.

\section{OVERVIEW OF THE FACTORING BUSINESS}

Factoring is a very old business, indeed, it was the dominant form of finance used in the American colonies before the Revolution. Factors were already common by the time of 
Hammurabi, four thousand years ago, when they would make advances to manufacturers or merchants against goods. Early factors might perform the selling function in addition to providing the credit and collection services. In colonial America, New York factors acted as sales agents for British and European textile mills, "selling the goods on a commission basis, perform[ing] the credit and collection function for their clients, guaranteeing the credits extended to their customers in this country, and advanc[ing] funds to the mills against these receivables and also against the goods received on consignment" (Phelps 1956, p. 65). Eventually, factors stopped acting as sales agents and specialized in providing credit and collection services. As the US textile industry developed, it followed the British and European practice of relying on factors for these services--and until this century, US factors focused almost exclusively on firms in the textile industry (including manufacturers, wholesalers, and retailers). It was not until the 1930s, partially due to the effects of the Great Depression, that factors expanded their business beyond textiles to wholesalers and retailers of other "dry goods". By the 1950s, factoring had spread to "bedding, chemicals, cosmetics, dry goods, electrical appliances and supplies, fertilizer, furniture, garden hose, gloves, hardware, hats, hosiery, house furnishings, housewares, infants' and children's wear, knit specialties, leather goods, linens, men's, women's, and children's apparel, metallic yarns, nylon fishing lines, paint, paper, piece goods, plastics, portable organs, radios, rubber goods, screening, shoes, sporting goods, thread, toys, and underwear." (Phelps 1956, p. $67-68)$

Factoring business reached a total of $\$ 260$ billion worldwide in 1991. In the U.S. the volume of factoring in 1993 was over $\$ 50$ billion. More than half of the worldwide volume of factoring business was in the US until quite recently, however, it experienced much faster growth outside the US during the 1980s; thus, the US no longer dominates worldwide volume--by the mid 1980s, the US share fell to less than half; by 1990 it was not much more than one-sixth. During the last half of the $1980 \mathrm{~s}$, factoring grew at a rate of $22 \%$ per year worldwide, but at a rate of only $8.4 \%$ per year (1985-90) in the US. Relatively slower growth in the US might be due to greater penetration into US markets than in the rest of the world, but may also be attributed to loss of US textile manufacturing--the traditional factor business. 
In the first six months of 1993 , factoring volume among the top 16 companies in the United States grew $6.9 \%$ (See Table III). The top 10 companies have over $90 \%$ of the volume.

Table III: Factoring Volume in the United States 1992-93 (Six months ending June 30, 1993, millions of dollars)

$\begin{array}{lrrc}\text { Company } & 1993 & 1992 & \% \text { Change } \\ \text { CIT Group/Com'1 Services } & 3,738 & 3,473 & +7.6 \\ \text { BNY Financial } & 3,650 & 3,350 & +9.0 \\ \text { NationsBanc Commercial } & 3,400 & 3,100 & +9.7 \\ \text { Heller Financial } & 2,919 & 2,967 & -1.6 \\ \text { Barclays Commercial } & 2,243 & 2,280 & +2.8 \\ \text { Republic Factors } & 2,325 & 2,080 & +11.8 \\ \text { Congress Talcott } & 1,915 & 1,735 & +10.4 \\ \text { BancBoston Financial } & 1,800 & 1,690 & +6.5 \\ \text { Trust Co. Bank } & 1,590 & 1,546 & +2.8 \\ \text { Rosenthal \& Rosenthal } & 620 & 620 & 0 \\ \text { Capital Factors } & 616 & 466 & +32.2 \\ \text { Milberg Factors } & 550 & 455 & +20.9 \\ \text { Midatlantic Commercial } & 455 & 474 & -4.0 \\ \text { Ambassador Factors } & 410 & 390 & +5.1 \\ \text { Merchant Factors } & 93 & 95 & -2.1 \\ \text { Standard Factors } & & & \\ \text { (Sterling National) } & 83 & 76 & +9.2 \\ \text { TOTAL } & \$ 26,507 & \$ 24,797 & +6.9\end{array}$

Source: Daily News Record, September 15, 1993, p. 8.

Though until the 1960s, most factoring was in the wholesale trade markets, and most of this in textiles and apparel, retail trade factoring surpassed that of wholesale factoring during the 1960s and now accounts for the dominant share. Also during the 1960s, commercial banks moved into the factoring sector by purchasing many of the leading factors. For example, in New York (the center of the textile/apparel trade and, thus, of factoring) there were 114 factors in 1935; there are now only 20 (Rutberg 1993). A handful of top banks now control the vast majority of factoring in the US--about $94 \%$ of factoring in the US is undertaken by bank-related factors. Concentration continues at a rapid pace; estimates are that half the existing factors will disappear or merge by the year 2000. Part of the reason for the consolidation is the consolidation of many 
of the clients of factors--in particular, retailers of consumer goods. It is estimated, for example, that half the retailers will also be gone by the year 2000 (Rutberg 1993). Another explanation is that commercial banks find it easier to buy factors than to set up their own operations. The US does not seem to be unusual on this score: the major clearing banks in the UK own the major factors. However, part of the explanation for the recent increase of consolidation is that the Justice Department has ignored mergers and concentration of the industry.

As mentioned, factoring has spread beyond textiles and apparel; clients of BNY factor (second largest in the US) now include metals manufacturers, glassware companies, and computer manufacturers. Newer clients of CIT Group/Commercial Services (the largest factoring company in terms of volume) include footwear, furniture, housewares, luggage, and electronics; in 1993, it is projected that volume of factoring of these newer businesses would be up $18 \%$, versus virtually flat volume for traditional apparel business. A large factor may have a wide variety of clients who are suppliers to a large retailer (say, Kmart), and the factor's bank affiliate may have a banking relationship with the retailer (Kmart). This means that the customer (Kmart) of the factor's clients (the various suppliers) is also a customer of the factor's associated bank--this gives the factor control over the customer that it would not normally have in the case of a very large retailer. Still, factoring has made relatively small inroads into the financial services market taken as a whole; for example, it is estimated that factors in the UK (a 200 billion pound sterling business annually) have captured only $6 \%$ of the potential factoring market. Only 12,000 firms (2\% of the total) in the UK use factors. In the US, total factoring business is equal to about $2.7 \%$ of total bank loans, or to nearly $10 \%$ of commercial and industrial loans. According to data from 1986 , accounts receivable were $21 \%$ of total US manufacturing corporate assets--this would seem to indicate that growth potential of factoring is large (Mian and Smith, 1992).

Growth potential appears to be large for several reasons. Many factors are just now moving out of the traditional sectors. Unlike a traditional credit line, a factoring facility grows automatically with a firm's business, making it attractive to rapidly growing firms. Banks appear to be restricting credit to smaller businesses, creating a niche for factors. Factors can provide a wide 
variety of services not normally offered by banks (as will be discussed). The recent recession (and the consolidation) has reduced credit-worthiness of many retailers (both small and large); their suppliers want to avoid credit risk and can do so by turning to factors. Firms that were the subject of LBOs during the 1980s are finding it difficult to obtain bank financing, thus, are more likely to turn to factors. Factors can help in work-outs of heavily indebted firms. Because factoring is often used in international trade (and particularly in trade which banks feel is too risky), there is a great opportunity for factors to finance trade in Eastern Europe and the former Soviet Union. US factors can also arrange partnerships with foreign factors that know the credit risk of overseas customers of US manufacturers. Exporters who use factors can ship goods without a letter of credit because the factor assumes the credit risk of the foreign customers. Factoring makes it easier for an inexperienced company to engage in exports since the factor will collect payment and might even offer currency exchange contracts to eliminate exchange rate risk (Hill 1992).

However, the relative success of factors and other "nonbank banks" does not appear to be due to onerous regulation of banks--Remolona and Wulfckuhler (1992) argue that if this were true, these would have done better than banks in all sectors of financial services industry, but this has not been the case. Rather, nonbank banks (including factors) have been more successful than banks only in niche markets. The niche market for factors appears to be newer, well- managed, highly profitable, but fast growing firms (and in particular, those with a rapidly growing working capital requirement). Niche factors have, however, provided capital to start-up businesses as well. As discussed below, there is a fundamental difference between normal bank lending and factoring: the bank's attention is focused on the credit-worthiness of the customer to which it is lending, while the factor is less concerned with the credit-worthiness of its client than it is with that of the client's customers. At the extreme, the factor's client may have no equity, no assets, and no credit record as in the case of start-up businesses; however, if the client's customers are creditworthy and the factor believes the client can deliver goods or services ordered by the customers, then advances can be made to the client once goods are delivered. One can imagine 
many cases in which the factor can fill a niche that could not be filled by a bank, given this difference of operating procedure.

Let us begin with a "plain vanilla" factor to explain what factoring is all about. First, a factor raises its funds through the issuing of commercial paper or other short term borrowings, and through notes and debentures. An established firm with an established customer base uses its credit line to meet a wage bill to produce the goods ordered by customers, who typically pay for the goods 30 days after delivery. It is not unusual for the firm to obtain a new customer that places an order too large to be filled with the existing credit line; however, the bank will not expand the line of credit because the firm has not yet experienced greater sales revenue, profit flows, or net worth position. The firm turns to a factor and sells the accounts receivable (the invoices for delivered goods, for which customers will pay 30 days hence) of established customers to the factor. (Factors will not normally purchase accounts receivable until goods are shipped, thus, the firm cannot sell the new invoices for goods to be produced.) The factor immediately advances to the firm (its client) $70-80 \%$ of the value of the invoices, which the firm can use to produce the goods to fill the new order. The new customer will then pay (30 days after delivery) the factor. When established customers pay their invoices, the factor will pay the remaining value of the invoices to the client, after subtracting a discount fee (ranging from less than $1 \%$ to as high as $5 \%$ ) plus interest on the advance for the period between the advance and the final payment by the established customers. This interest rate is usually prime plus 2 percentage points. If the customers are late in paying the invoices, the discount fee can be higher, and the interest cost is higher (since the finance period is longer).

There are two complications that immediately arise if a customer refuses to pay the invoice. First, this refusal might be the fault of the client firm--perhaps the good or service was never delivered or was of inferior quality. The factor has protected itself from this in the original agreement; thus, the client will be liable for payment of the advance (plus interest and the fee). On the other hand, the customer might simply default. Most factoring agreements include credit insurance so that 
the client would not be liable for default--indeed this is one of the principal attractions of factoring over bank-supplied credit.

The "minimal" factoring service, then, is normally one of purchasing of accounts receivable on a non-recourse, notification basis. This means that the client is not liable for credit risk (non-recourse) and that customers are notified that they are to pay the factor directly. This is much different from bank lending against accounts receivable, where: a) the bank will usually lend only $50 \%$ of the value of the collateralized accounts receivable; b) the bank does not assume credit risk; and c) the firm would continue to collect invoice payments.

While the factor is usually liable for credit risk of the customers of its client, in some cases factors use "refactoring" to limit their services to only the marketing end of the business. In this case, one factor might market various services to local business and sell its accounts receivable business to another factor, which would then be responsible for billing and collection. In these "refactoring" arrangements, typically a small factor develops close relations with local businesses as it markets the services that are ultimately provided by a larger factor (often, one of the "megafactors" discussed below). In some cases, these smaller factors specialize in providing a very narrow range of services as "niche" factors, as will be discussed below. The "refactoring" business is particularly suited to international trade, where the local factor can determine creditworthiness of domestic customers and agents of a foreign client serviced by a foreign factor.

However, "full service factoring" typically includes purchasing of accounts receivable and providing bookkeeping, billing, and collection services. These services are included in the discount fee paid by the client to the factor. In addition, a factor might offer data processing services, provide counseling services, take over the sales ledger, conduct sales analyses, handle customer orders, provide inventory records and inventory control, conduct cost analyses, and might even be able to bring new customers to the client. This makes the factor a legitimate financial services center. 
At the extreme, the factor assumes the client has no credit, thus, the factor will not be able to collect anything from the client should the customer default. The factor will closely examine potential customers and decide which ones are credit worthy; it is then willing to purchase the invoices of these. Advances will not be made against the invoices of those whose creditworthiness is not established, which means that the client cannot ship merchandise to them unless it is willing to assume credit risk and can wait the normal 30 days or so for payment. Factors traditionally will not finance orders, but will only provide finance once the merchandise has been shipped. Factors (like banks) set a minimum size relationship depending on their own cost structure. It appears that the minimum size firm that a factor is willing to service is on the order of half a million dollars in annual sales revenue. Larger factors would presumably set a higher minimum. In foreign trade, the minimum volume that would interest a factor appears to be $\$ 2$ million of annual sales.

A firm that sells its accounts receivable to a factor immediately improves its balance sheet position because approximately $80 \%$ of the receivables are transformed into cash; on the balance sheet of the firm, the sold receivables are "netted" against the "loan" made by the factor when it discounts the receivables. If the firm had instead chosen to use accounts receivablc as collateral against a loan advanced by a commercial bank, its balance sheet would not look nearly so favorable. This is illustrated by the example in Figures 1 and 2, which are adapted from Lux (1988).

In Figure 1, a typical balance sheet is shown for a firm that has pledged accounts receivable against a commercial bank loan. As mentioned above, banks will normally advance only 50\% of the value of the accounts; however, in our example, we have assumed the bank advances $80 \%$ of the value of the accounts in order to make this example consistent with the example using finance provided by a factor. As shown in Figure 1, the firm has pledged $\$ 200,000$ of accounts receivable against a loan of $\$ 160,000$; the firm's total liabilities are $\$ 470,000$ while its current assets total $\$ 620,000$ and its net worth is $\$ 200,000$. This gives a working capital ratio (assets over liabilities) of 1.32 and a debt-to-net-worth ratio of 2.35 . 
Figure 1: Balance Sheet--Accounts Receivable Financing by a Commercial Bank.

\begin{tabular}{||lr|lr||}
\hline \hline Cash & $\$ 20,000$ & Accounts Payable & $\$ 300,000$ \\
\hline $\begin{array}{l}\text { Accounts Receivable (Pledged to Secure Bank } \\
\text { Loan) }\end{array}$ & 200,000 & Due to Bank (Secured by Receivables) \\
\hline Inventory & 400,000 & Accrued Expenses & 160,000 \\
\hline Current Assets & 620,000 & Current Liabilities & 10,000 \\
\hline Fixed Assets (net) & 50,000 & Net Worth & 470,000 \\
\hline Total & $\$ 670,000$ & Total & $\$ 200,000$ \\
\hline Working Capital Ratio 620,000/470,000 $=1.32$ & Debt to Net worth Ratio 470,000/200,000 \\
\hline
\end{tabular}

Source: Lux 1988.

Figure 2: Balance Sheet--Financing through a Factor

\begin{tabular}{||lr|lr||}
\hline \hline Cash & $\$ 20,000$ & Accounts Payable & \\
\hline Due from Factor & 40,000 & & \\
\hline Inventory & 400,000 & Accrued Expenses & 10,000 \\
\hline Current Assets & 460,000 & Current Liabilities & 310,000 \\
\hline Fixed Assets (net) & 50,000 & Net Worth & $\$ 200,000$ \\
\hline Total & $\$ 510,000$ & Total & $\$ 510,000$ \\
\hline Working Capital Ratio $460,000 / 310,000=1.48$ & \multicolumn{2}{|l|}{$\begin{array}{l}\text { Debt to Net worth Ratio } 310,000 / 200,000= \\
1.55\end{array}$} \\
\hline
\end{tabular}

Source: Lux 1988.

In the case of financing through a factor, the firm does not carry either the accounts receivable or the advance on these accounts on its balance sheet because it has sold these accounts rather than pledged them as collateral. Thus, the firm only carries the amount due from the factor $(\$ 40,000)$ as an asset. In this case, the firm's working capital ratio is 1.48 and its debt-to-net worth-ratio is 1.55. Clearly, it is more advantageous to the firm to use the factor. Our example has even understated the advantage of factoring because in most cases, the bank will advance 
only $50 \%$ of the value of the receivables (as opposed to $80 \%$ in the case of factoring). Furthermore, the accounts receivable pledged against the bank loan are carricd on the books as an offset to the amount due to the bank. In other words, there is no "netting" in the case of pledged receivables as there is in the case of receivables sold to a factor. The debt-to-net-worth of the firm relying on the bank loan will look much worse than that of the firm using factoring; furthermore, the factored firm will appear more "liquid" in terms of its working capital ratio (current assets over current liabilities). In addition, bank loans usually require compensating balances, tying up liquid resources of firms, while factoring does not (Lux 1988).

However, factoring is not suitable for all lines of business. Factoring may be most appropriate in industries that have large markups, as in the apparel business. First, factoring is advantageous where there is a temporal gap between the time a service or merchandise is provided and the time when payment is received. The desirability of factoring also increases as the unit markup (the difference between the cost of providing the service or good and the price charged to the customer) rises because finance obtained through a factor is more expensive--in part because factors rely on more expensive sources of funds (as discussed below, usually on commercial paper) when compared with banks. Obviously, the desirability of factoring will decline as the discount fee charged rises; as the percent of the value of accounts receivable advanced declines; and as the interest rate charged on advances (a function of the factor's cost of funds and the credit risk of customers) rises. While factoring is more expensive as a source of credit that is bank finance, it must be emphasized that factors provide more services and provide larger advances against accounts receivable than do banks. Again, factoring is not for all lines of business.

Factors primarily rely on commercial paper, short-term borrowings, notes, debentures, and subordinated notes and debentures to finance their positions in receivables. According to 1992 balance sheet data for one of the largest factor companies, commercial paper accounted for 39\% of liabilities while notes and debentures equaled $57 \%$ of liabilities. The equity-to-asset ratio for this factor was $14 \%$, while its allowance for losses on receivables equaled $3 \%$ of assets. More 
than $90 \%$ of this firm's equity was in the form of common stock, with less than $10 \%$ in the form of preferred stock. Of course, these figures would not be strictly applicable to all factors, and would deviate considerably from those of smaller factors which might be closely held and might have restricted access to the commercial paper market.

\section{MEGAFACTORS, NICHE FACTORS, AND COMMUNITY-BASED FACTORS}

In the 1960s, the Comptroller of the Currency allowed commercial bank holding companies (BHCs) to purchase factors, fueling a merger and consolidation wave that created huge factor companies--the "megafactors"--the top dozen or so factors. As discussed above, the vast majority of the volume of factoring is undertaken by BHC-owned factors; similarly, the vast majority of the volume of factoring is undertaken by the megafactors, most of which are BHC-owned. At the same time, the number of community-based, primarily independent, factors has declined absolutely--and their share of the volume of factoring has declined even faster. However, simple extrapolation of these trends would lead to mistaken projections. The prospects for the megafactors are quite different from those of the community-based factors--the megafactors are involved in the highly competitive financial sector that serves primarily medium-to-large corporations that are able to use a wide variety of alternative sources of financial services, while the community-based factors serve niche markets that are not subject to these same competitive forces.

\section{A) Megafactors}

Total US factoring volume grew from $\$ 26$ billion in 1978 to $\$ 46$ billion in 1988 (and a projected $\$ 52$ billion in 1993), of which the vast majority (about $94 \%$ ) was undertaken by BHC-owned megafactors (Matthesen 1992). Between 1981 to 1987, the number of major factors declined from 35 to 23, and the number declined further to 15 by 1993 (Doherty 1993 and Andersen Consulting 1990a). In November 1993, it was announced that CIT was to buy Barclays Commercial, which would create the largest factoring company combination ever. As discussed above, commercial 
banks had moved into factoring since the 1960s, and by the mid 1970s, BHC-owned factors were dominant. The primary reason for such bank purchases was the perceived high return on assets and equity in the factoring business. However, between 1983-88, most of the large money-center banks sold their investments in factors because they found the business was too labor-intensive.

Their position was taken by regional banks which believed they could reduce costs and increase the volume of factoring (Andersen Consulting 1990a). Recent data appears to demonstrate that they have been successful at expanding business, increasing or at least maintaining profitability, and minimizing losses (Andersen Consulting 1990a). The volume of factoring business continued to grow in the first half of 1993 even with the sluggish economy and a depressed apparel industry. While factoring in the apparel business was essentially flat, new business in nontraditional areas accounted for most of the growth.

By mid 1993, the three largest factors were CIT, BNY Financial Company, and NationsBanc Commercial; these experienced growth of $7.6 \%, 9 \%$, and $9.7 \%$ respectively in the first half of 1993 compared to the similar period of 1992 (see Table III). CIT's total volume over the six month period was $\$ 3.7$ billion, while BNY's was $\$ 3.65$ billion; BNY expects to do $\$ 7.5$ billion of factoring business in 1993, compared with $\$ 7$ billion in 1992. As mentioned, CIT (jointly owned by Dai-Ichi Kangyo Bank Ltd and Chemical Banking Corporation) has agreed to acquire Barclays Commercial Corporation; the two firms combined had factoring business equal to about $\$ 12$ billion in 1992 or about $23 \%$ of the volume of the top 16 companies.

Crocker Bank's experience with United Factors is an example of what can go wrong when a commercial bank moves into the factoring business (Rutberg 1989). In 1978, United Factors had a factoring business of nearly $\$ 2.5$ billion--the largest in the business. Crocker National bank was in negotiations to purchase United just as United was filing for bankruptcy under Chapter XI--a bankruptcy forced to a great extent by the failure of one of its largest customers. Crocker purchased United, anyway, but found that retail factoring (about 60\% of United's total business) was labor-intensive and costlier than expected. It also discovered that it had to take write-offs 
as a regulated institution that United had not been forced to take--leading to losses that had not been recognized by United. It also found that factors are highly specialized service companies with a mercantile business that conflicted with a banking culture. Thus, in 1981, Crocker decided to get out of factoring.

Large megafactors tend to be successful when they take advantages of large economies of scale and produce high volumes of factoring business per employee (Andersen Consulting 1990a, $1990 \mathrm{~b}$ ). This dictates a narrower range of services as the megafactor focuses on "plain vanilla" factoring, and particularly on purchase of receivables, providing credit insurance, and providing letters of credit. Indeed, megafactors are increasingly factoring with recourse, in which case their clients are responsible for the debts of customers. In this case, the megafactor does not assume credit risk of customers, rather, is subject only to credit risk of clients. This sort of business favors larger manufacturers or retailers who are credit-worthy and who have billing and collection departments. These generally have access to alternative forms of finance and turn to factors when they can offer competitive financing arrangements.

Megafactors can compete successfully with commercial banks in the accounts receivable business because the Federal Reserve requires that banks hold equity against the total volume of accounts receivable purchased, while factors only consider the net funds at risk--that is, the difference between accounts receivable purchased and credit balances. Banks then typically measure the profit rate as the ratio of pretax returns to total assets, while factors measure the profit rate as the pretax return on average net cash employed. If credit balances are equal to half the total of accounts receivable, then the measured rate of profit for a factor will be, for example, twice that of a commercial bank engaged in the same business (Andersen Consulting 1990a). On the other hand, megafactors could face rising competition from finance companies, which are now larger than factors. Like factors, finance companies engage in asset-based lending, lending against collateral such as inventory, equipment, receivables, and real estate. Unlike factors, however, finance companies hold a lien on the collateral rather than taking title to the collateral. 
Andersen Consulting has released two reports on the factor business and foresees hard times ahead for megafactors (Andersen Consulting 1990a, 1990b). Although these recently have been moving into other areas, the vast majority of the business of megafactors remains in the textile and apparel industry. This industry is going through rough times, partially due to sluggish retail sales, to high leverage and overambitious expansion that occurred during the 1980s, and to resulting bankruptcies and consolidations. Andersen predicts that when a few, healthy retailers emerge and the sector stabilizes, it will seek non-factor finance. Furthermore, recent changes in production methods and inventory management have reduced the time required for production, distribution, and final sale for apparel; this time-gap is essential for the factoring business and as the temporal gap between production and final payment declines, discounting of accounts receivable becomes less desirable compared to traditional forms of finance.

In order to grow, megafactors need to move into new areas, diversifying out of textiles and apparel; they will need to increase the pace of innovation (in general, innovations in factoring have been at the niche level) so they can maintain market share in the presence of competition from other asset-based lenders, in particular, finance companies; and they need to increase their presence in international trade finance. A major opportunity is to develop "pipeline finance", for example in an industry in which a single factoring company finances the total production-tomarket movement of a product, dealing directly with the materials suppliers, the manufacturer, the wholesaler, and the retailer.

\section{B) Niche Factors}

Niche factors operate in the small-to-medium sized firm sector, generally providing a much broader range of services to their clients than do the megafactors. We will distinguish the "niche factor" from the "community-based factor", although in the past, these were essentially the same thing. Until quite recently, the typical niche factor was small, independent, community-based (most located in New York City), and provided finance to textile and apparel firms. However, as the term is now used, niche factors are those which service small-to-medium size clients in 
a particular industry without regard to the "community" in which each is located, although niche factors may tend to be regionally-based.

The type of niche factor that is growing at the fastest pace is that which specializes in providing services to medium-small sized manufacturers in a particular industry with sales of half a million to five million dollars annually (Rutberg 1993). For example, Omni Commercial Corporation is a niche factor whose small manufacturing clients average about $\$ 1.5$ million in sales annually; another niche player, Merchant Factors, does about $\$ 180$ million of business annually with small manufacturers, which it actively recruits and tries to help grow. When a manufacturer becomes too large, Merchant will seek participation by another lender or will refer the manufacturer to a megafactor. As another example, Century Business Credit Corporation recently created a new division, Century Factors, that will provide factoring services to small businesses with sales between half a million and three million dollars annually; once a firm achieves sales greater than $\$ 3$ million, it will become a client of the parent, Century Business.

Recently, China Trust Bank started a factoring company to serve manufacturers with annual sales of $\$ 100,000$ to $\$ 5$ million in the apparel manufacturing business. It is primarily organized as a niche factoring department that specializes in "refactoring" using a megafactor, to provide credit checking and back office services for China Trust. This enables China Trust to operate its factoring department with a minimum of employees. Niche factors serve small manufacturers, some with as little as $\$ 100,000$ in annual revenue, and according to the President of China Trust Bank, Thomas Chen, the market niche has "excellent growth potential and brings all the services of the bank together" (Daily News Record, September 17, 1993, 10). The niche factors are also able to provide counseling and hands-on service to new and growing companies.

Niche players are primarily independent (not BHC-owned) and information-intensive factors that develop close relations with their clients. They have been moving into new areas, such as healthcare and high tech sectors. They have also been innovative in the types of services provided to clients, even taking equity interest in small firms. Compared with megafactors, their labor 
costs are higher and volume per employee is lower. They are able to reduce costs to their clients, however, by providing a wide range of services that a small business may not be able to selfprovide, including billing and collection services, sales analysis, and recruitment of new customers. Niche factors also provide letters of credit for their clients and are willing to provide credit in addition to financing accounts receivable. In some cases, they are able to attract equity investments into small business by improving the balance sheets of the customers; they also make it easier for the small firm to obtain credit from commercial and investment bankers by improving balance sheets and establishing credit records for clients. Niche factors are particularly important for fast-growing firms--since the factoring volume increases automatically with sales. A recent study has found that most employment growth is generated by "gazelles"--those firms that are growing fast--rather than by small or large firms, per se (Birch and Medoff 1993). Niche factors can play a significant role in stimulating the economy by financing the small-to-medium size gazelles.

Although costs of using niche factoring are high relative to traditional bank credit, factors provide more services. As discussed, these services tend to be those which small firms are least able to provide themselves. In any case, the cost of credit may not be of overriding significance in the case of fast growing firms, which appear to find quantity constraints more important (Fazzari 1993). Niche factors are also willing to accept smaller minimum guaranteed fees than megafactors, and service clients with far smaller equity. Because the niche factors are often small, privately held firms, data on their factoring volume is not easily obtainable. However, niche factoring is growing rapidly, and is an extremely profitable business (Rutberg 1993, Doherty 1993).

As indicated by the term "niche factor", these have found a market that is unlikely to be serviced by other financial firms--whether megafactors, finance companies, or commercial banks. Thus, unlike the case of megafactors, the prognosis for niche factors is for continued strong growth. For example, since 1991, the number of niche factors servicing only small apparel manufacturers has grown from two to six (Doherty 1993). 
c) Community-based Factors

A community-based factor (CBF) is a particular type of niche player whose niche is a community rather than a particular type of industry. For example, a CBF might provide financial services to local manufacturers, wholesalers, and retailers. Its typical client would probably be smaller than even that of the niche factor discussed above--perhaps in the range of $\$ 75,000$ to half a million sales annually. This is a substantially untapped market. Factoring companies such as China Trust are intimately connected to the communities they serve and provide a model for the establishment of community-based factors. They can play a major role in the revitalization of communities. CBF's can offer management advice, provide equity directly or indirectly (by pursuing sources for clients), help arrange credit lines, supply billing and collection services, and buy accounts receivable.

As part of our proposal (Minsky et al 1993) to develop a system of CDBs, we called for the creation of commercial bank and investment bank "subsidiaries" of the CDB to provide "ordinary commercial bank business for clients in its neighborhood", including business checking accounts. In addition, the "investment bank subsidiary" would provide equity and "longer-term debt funding to existing business as well as new business in its community". We recognized that one function of the loan officer of the $\mathrm{CDB}$ is to "discover the potential entrepreneurial resources in the community that require financing." We also recognized that the duties of the loan officer include developing knowledge regarding the business prospects of the community, soliciting business for the $\mathrm{CDB}$, structuring loans to meet the needs of clients, and supervising loans to ensure minimal losses.

It is clear that a CBF can operate as an adjunct of the commercial and investment banking arms of a CDB. Like the loan officer of these subsidiaries, the supervisor of the factoring business must develop intimate knowledge of the credit-worthiness of the businesses in the serviced community. The CBF will be able to provide finance in cases where the commercial and investment subsidiaries are not able to do so--in particular, the CBF can provide finance to the 
rapidly growing firms that have good, credit-worthy customers. We envision the possibility that many minority-owned service sector firms could qualify for CBF financing, even where they cannot obtain more traditional finance, when the customers they serve can provide discountable invoices. Similarly, small manufacturing firms that provide finished or partially finished products to credit-worthy manufacturers, wholesalers, or retailers are potential clients of the CBF subsidiary of the CDB. The CBF may also be able to recruit equity funding for its clients where growth potential appears good. Because it is the credit-worthiness of the customers, and not of the clients, that is crucial for the success of the CBF, it may turn out that factoring is superior for the financing of small business in depressed communities than is financing that can be provided by commercial and investment banking--even when compared with that of the commercial and investment banking subsidiaries of a $C D B$. Factoring is particularly suited for relatively lower volume, higher markup business in which slightly higher interest costs of factoring are more than offset by reduction of billing and collection costs, and the costs associated with more traditional sources of finance.

\section{POLICY IMPLICATIONS}

Two previous Public Policy Briefs have dealt with the role that community development banks (CDBs) can play in enhancing the Community Reinvestment Act (CRA) and in revitalizing economically distressed communities (Minsky, Papadimitriou, Phillips, and Wray 1993; Papadimitriou, Phillips, and Wray 1993). We believe that the CBFs have an important role to play in this endeavor, particularly because these can provide niche finance to small business in the distressed communities and help to generate employment opportunities where they are most needed. If, as seems clear from the anecdotal evidence, redlining and discrimination in lending are common in these neighborhoods, and if small business, generally, faces a credit crunch, then programs that can increase the supply of credit to small business in these communities are desperately needed. The CBFs would supplement other efforts, including CDBs, community credit unions, etc. We certainly don't envision CBFs as fulfilling all needs in these communities-rather, they will fulfill some of the specific needs of certain types of firms. In particular, CBFs 
will target relatively rapid growing, small firms that provide intermediate and finished goods or services to credit-worthy customers.

Data on mortgage lending and on payment services provided to households clearly demonstrate that some communities are underserved (Papadimitriou, Phillips, and Wray 1993). Unfortunately, comparable data on commercial lending does not exist. However, we believe that sufficient evidence does exist to allow a presumption that there are underserved communities that would benefit from increased lending to small firms. We also believe that some of this unmet need could be met by extension of factoring into these communities. In one of our earlier Public Policy Briefs, we argued that the main function of the financial structure is to advance the capital development of the country, and that this is encouraged by the provision of a broad range of financial services to various segments of the US economy, including consumers, small and large businesses, retailers, developers, and all levels of government (Minsky, Papadimitriou, Phillips, and Wray 1993). We also argued that the existing financial structure is particularly weak in servicing small and start-up businesses, and that this problem has become more acute because of a decrease in the number of independent financing alternatives and the rise in the size distribution of financing sources. For these reasons, we called for the development of a system of CDBs. The President's CDFI proposal is a movement in that direction. Extension of his proposal to include a role for CBFs would help to meet the concerns we have raised here and in our previous Public Policy Briefs.

The "factoring" part of the CDB could provide various services to small firms, including payroll, bookkeeping, and collection services. At the same time, this seems to be a way to provide working capital to small and start-up firms but with very little credit risk for it is the customer of the firm whose credit worthiness is important. Existing factors sometimes inject capital into their clients, or bring together venture capitalists and their clients. Such solicitation would seem to be appropriate in the case of CBFs. In some cases, existing CBFs would be allowed to join the proposed system of CDFIs; in other cases, a CBF might become a subsidiary of a new or existing CDB. Finally, some new CDFIs might choose to develop factor subsidiaries. So long as 
the factoring business of the CBF (whether independent or part of a CDB) serviced communitybased firms in distressed communities, there is no reason why it should not have access to funding provided by President Clinton's CDFI program.

The Small Business Administration can provide leadership in encouraging factors to lend to small business. In the case of bank-owned factors, lending to small business in the bank's community as defined for CRA compliance could count toward fulfillment of its CRA obligation. We also recommend that President Clinton's CDFI proposal approved by Congress provide a significant role to be played by factors to increase lending to small business. In some cases, a CDB might run a factor subsidiary directly; in other cases, an existing factoring company might qualify as a CDFI and be eligible for funding under the President's plan.

In our Public Policy Brief \#6 (Papadimitriou et al 1993), we called for strengthening of the CRA and for commercial bank investments in CDBs as part of CRA compliance. It is clear that commercial bank investments in CBFs should also count toward CRA compliance to the extent that this encourages lending by the CBFs in the communities of the commercial banks (as defined for CRA compliance). In this way the CBFs would complement existing and proposed programs to ensure that financial services are supplied to presently underserved communities. As we argued previously, "it is unrealistic to expect that any financial institution can meet all the needs of any community", thus, there is a role for CBFs to play in distressed communities. As we have argued before, we do not believe that small business, by itself, can be the engine of growth for the whole US economy. However, increased lending to small business can help to enlarge employment opportunities, in general, and economic opportunities in distressed communities, in particular-even if this by itself does not solve the significant problems facing the US economy today and in the foreseeable future. 


\section{BIBLIOGRAPHY}

Andersen Consulting. "The Asset-Based Financial Services Industry: Past, Present, and Future," New York, March 6, 1990.

_, "Future: Trends in Asset-Based Financial Services," New York, Jul 5, 1990.

Baris, Jay G., "Regulating Banks: Enough Already", The New York Times, February 7, 1993, p. 13.

Batchelor, Charles, "Lenders of Last Resort?", Accountancy, September, 1992, pp. 76-78.

Birch, David and Medoff, James. "Gazelles," Paper presented at the Milken Institute Conference, November 1-13, 1993, Washington, D.C.

Boyd, John H. and Graham, Stanley L., "Investigating the Banking Consolidation Trend," in The Commercial Bank Management Reader, cdited by Robert W. Kolb, Miami: Kolb Publishing Company, 1992, pp. 69-81.

Bradbury, Katherine L., Case, Karl Ei., and Dunham, Constance R., "Geographic Patterns of Mortgage Lending in Boston, 1982-87," New England Economic Review, September/October 1989.

Carr, James. H. and Megbolugbe, Isaac F. "Another Look at the Boston Fed's Mortgage Discrimination Study," Housing Research News1 (December 1993).

Daily News Record, September 15, 1993. 
Davis, Stephen, Haltiwanger, John, and Schoh, Scott, "Small Business and Job Creation: Dissecting the Myth and Reassessing the Facts," forthcoming in L. Solmon and $\Lambda$. Levenson. eds., Labor Markets, Employment Policy, and Job Creation. Boulder: Westview Press.

DeYoung, Robert and Gary Whalen. "Banking Industry Consolidation: Efficiency Issues," paper presented at a conference on "The Financial System in the Decade Ahead: What Should Banks Do?" at the Jerome Levy Economics Institute of Bard College, April 14-16, 1994.

Diamond, Stephen C., "Convention Keynote Address", NCFA Journal, January, 1985, pp. 64-68. Doherty, Bryan, "Factoring-What Does the Future Hold?", The Secured Lender, September/October 1986, pp. 4-6.

. "Niche Factoring Finds Fertile Field in Funding Small Apparel Firms," Daily News Record, September 17, 1993, pg. 10.

Fazzari, Steven. The Investment-Finance Link: Investment and U.S. Fiscal Policy in the 1990s. Public Policy Brief No. 9/1993, The Jerome Levy Economics Institute of Bard College, 1993.

Federal Financial Institutions Examination Council. Uniform Bank Performance Report. Washington, D.C.

French, George. "Banking in Transition," paper presented at a conference on "The Financial System in the Decade Ahead: What Should Banks Do?" at the Jerome Levy Economics Institute of Bard College, April 14-16, 1994.

Hawkins, Richard William, "The Calvary is on the Horizon", The Secured Lender, March/April, 1993, p. 42. 
Hill, Donna, "Factoring Becomes Fashionable", The Secured Lender, March/April, 1992, pp. 34-40.

Jordan, Jerry. "Community Lending and Economic Development," Speech at the Federal Reserve Bank of Cleveland's Community Reinvestment Forum in Columbus, Ohio, Economic Commentary, Federal Reserve Bank of Cleveland, November 15, 1993.

Kaminski, Harvey L., "A Practical Guide to Verification/Notice Financing", The Secured Lender, September/October, 1992, pp. 59-61.

Kiefer, John W., "Secured Lending-Financing Accounts Receivable: The Role of Factors", Commercial Lending Review, Fall, 1992, pp. 86-88.

Klemme, Kelly, "Bank Credit to Small Business: What Do the New Data Reveal," Financial Industry Issues, Federal Reserve Bank of Dallas, Quarter 3, 1993.

Kohn, Richard M., "Reflections on International Asset-Based Lending", The Secured Lender, January/February 1991, pp. 8-28.

Lindsey, Lawrence. "Statement to Committee on Banking, Housing, and Urban Affairs, U.S. Senate, November 4, 1993, Federal Reserve Bulletin, January 1994, pps. 10-19.

Lux, Joseph F., "The Factoring Advantage", The Secured Lender, November/December, 1988, pp. 86-89.

Matthesen, Thomas, "Factoring: The Service Challenge for the Nineties", The Secured Lender, March/April, 1992, pp.54-58. 
Mian, Shehzad L. and Smith, Clifford W. Jr., "Accounts Receivable Management Policy: Theory and Evidence", Journal of Finance, March, 1992, pp. 169-200.

Minsky, Hyman P., Dimitri B. Papadimitriou, Ronnie J. Phillips and L. Randall Wray. Community Development Banking: A Proposal to Establish a Nationwide System of Community Development Banks No. 3/1993, The Jerome Levy Economics Institute of Bard College.

Munnell, A.H., L.E. Browne, J. McEneaney, and G. Tootell. 1992. "Mortgage Lending in Boston: Interpreting the HMDA Data" Federal Reserve Bank of Boston, Working Paper no. 92-7

Nolle, Daniel E. "Banking Industry Consolidation: Past Changes and Implications for the Future," paper presented at a conference on "The Financial System in the Decade Ahead: What Should Banks Do?" at the Jerome Levy Economics Institute of Bard College, April 14-16, 1994.

Papadimitriou, Dimitri B., Ronnie J. Phillips and L. Randall Wray. A Path to Community Development: The Community Reinvestment Act, Lending Discrimination, and the Role of Community Development Banks No. 6/1993, The Jerome Levy Economics Institute of Bard College.

Pechter, Kerry, "Who Needs Banks?", International Business, September, 1992, pp. 48-54.

Phelps, Clyde William. The Role of Factoring in Modern Business. Baltimore: Commercial Credit Company, 1956.

Quickel, Stephen W., "Providing Credit Where Due", International Business, January, 1993. pp. 26-28.

Remolona, Eli M. and Wulfekuhler, Kurt C., "Finance Companies, Bank Competition, and Niche Markets", Quarterly Review, Federal Reserve Bank of New York, Summer, 1992, pp. 25-38. 
Rutberg, Sidney. "Factoring and Commercial Finance in the Year 2000", The Secured Lender, January/February, 1993, pp. 26-31.

, "The Fall of United Factors", The Secured Lender, November/December 1989,

pp. 18-24.

Samolyk, Katherine A. and Rebecca Wetmore Humes, "Does Small Business Need a Financial Fix?", Economic Commentary, Federal Reserve Bank of Cleveland, May 15, 1993.

Schlegel, Michael T., "Putting the Merchant back into Banking", The Secured Lender, January/February 1990, pp. 16-18.

Simonson, Donald G. "Business Strategies: Bank Commercial Lending vs. Finance Company Lending," presented at a conference on "The Financial System in the Decade Ahead: What Should Banks Do?" at the Jerome Levy Economics Institute of Bard College, April 14-16, 1994.

Slater, Robert Bruce, "Banks are a Big Factor in Factoring", Bunkers Monthly, January 1993, pp. 37-38.

Spragins, Ellyn E., "Low-Brow Finance", INC., May, 1990, pp. 109-110.

Stuchin, Miles. "Factoring: Is the Category Getting Killed?", The Secured Lender, November/December, 1991, p. 86.

Wheelock, David. "Is the Banking Industry in Decline? Recent Trends and Future Prospects from a Historical Perspective." Review. Federal Reserve Bank of St. Louis. 75 September/October, 1993. 